\title{
Poultry Manure and NPK Fertilizer Application and their Residual Effects on the Yield and Yield Components of Tomato (Lycopersiconesculentum. Mill) in two Distinct Ecological zones of Central Southern Nigeria.
}

\author{
Isitekhale, H.H.E ${ }^{1}$ Osemwota, I.O ${ }^{1}$ andAmhakhian, S.O ${ }^{2}$ \\ ${ }^{I}$ (Department of Soil Science, Faculty of Agriculture, Ambrose Alli University, Ekpoma, Edo State, Nigeria). \\ ${ }_{2}^{2}$ (Department of Soil Science, Kogi State University, Ayingba, Kogi State, Nigeria).
}

\begin{abstract}
Field experiments were conducted in two ecological zones of Central Southern Nigeria; Agbede (derived savanna) and Obadan (forest) of Edo State to investigate poultry manure and NPK fertilizer and their residual effects on performance of tomato. The treatments consisted of three levels of poultry manure $(0,4$ and 6

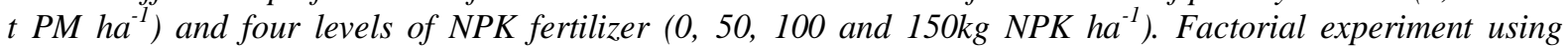
randomized complete block design was engaged. Plant height and leaf area were significantly increased by the application of 6 t PM ha $a^{-1}$ and 6 t PM ha- plus 50kg NPK ha $a^{-1}$ and $6 t P M \mathrm{ha}^{-1}$ plus $100 \mathrm{~kg} \mathrm{NPK} \mathrm{ha}^{-1}$ in both locations and years, respectively. The application of $4 t P M \mathrm{ha}^{-1}$ alone in 2005 and its residual effects significantly enhanced plant height and leaf area in both locations. In Obadan soils, optimum fruit yields of 3.42 and $2.85 \mathrm{th} \mathrm{h}^{-1}$ were obtained from the combined application and residual6 tPM hal plus $100 \mathrm{~kg} N P K \mathrm{ha}^{-1}$, while in Agbede soils, optimum fruit yields of 1.44 and $1.55 \mathrm{th} \mathrm{h}^{-1}$ were obtained from the application and residual 6 t PM ha- plus 50kg NPK ha-l and their residual effects respectively. Responses to manure fertilizer mixtures are higher in the forest compared to the derived savanna ecological zone of Nigeria.
\end{abstract}

Key Words: Application, Fertilizer, Manure, Tomato and Yield.

\section{Introduction}

Tomato (Lycopersiconesculentum. Mill) is cultivated throughout tropical Africa and South America and southern Italy (1). Most tomatoes grown in West Africa are local cultivars whose resistance to diseases is usually good (2).

Nitrogen, P and K, among others are known to affect yield (3). Deficiency in K affects fruit size and quality rather than numbers. Organic manure has been identified as a potential source of nutrients in vegetable production (4) and has also be studied on other crops such as maize $(5,6)$. Recent studies have shown that the use of commercial fertilizers in Nigeria for crop production is limited by their scarcity and high cost (7). Small farm holders in tropical Africa and Latin America rarely use organic fertilizers on food crops (8). Poultry manure is a source of organic manure from livestock that enriches the soils, it does not only increase the nutrient status of the soil but improves the structure (9).Poultry manure should be managed for its $\mathrm{N}$ value(11). Poultry manure may have higher values for $\mathrm{P}$ and $\mathrm{K}$ (12). About $70 \%$ of $\mathrm{N}$ in poultry manure can be available to the crop during the first year of application (10).

Many workers in Nigeria had researched extensively on the effects of fertilizers on crop growth and yield. NPK fertilizer application sustains soil fertility and crop production(11). It was also reported that NPK fertilizer increases okra height, leaf area and yield components (13). Lower rates of application were also observed to increase maize yield significantly (14). The application of $300 \mathrm{~kg} \mathrm{ha}^{-1} \mathrm{NPK}$ fertilizer to cassava increased dry matter parts (leaves, stem and tubers) in comparison to $10,100,200$ and $400 \mathrm{~kg} \mathrm{ha}^{-1}$ NPK (15).

It is important for farmers to manage their organic residues alongside mineral fertilizers that are in short supply and scarce (16). Application of $10 \mathrm{t} \mathrm{PM} \mathrm{ha}^{-1}$ and combinedapplication of $5 \mathrm{t} \mathrm{PM} \mathrm{ha}^{-1}+\mathrm{NPKMg}$ (50:35:55:20kg $\mathrm{ha}^{-1}$ ) fertilizer gave higher maize crop growth and yield when compared to NPK fertilizer alone(17).

Poultry manure, when combined with mineral fertilizer can exhibit long residual effect, which improves growth and yield (18). Poultry manure alone or in combination with mineral fertilizer exert more beneficial effects on fruit yield when compared to fertilizer applied alone(19).A practical approach to poultry manure handlingis to characterize the waste material before it can be appropriately used as soil amendment because variation is introduced by differences in species of animal used, housing systems and age even within a specific operation, the characteristics of the manure will be influenced greatly by the ration, the type of bedding and the handling system (20).Poultry manure alone and its combination with NPK fertilizer in first year of application and their residual effects improved degree of saturation, soil moisture content and lower soil bulk density in both forest and savannah zones, it was significantly better in the forest soils. Better water stable aggregate, porosity, void ratio and air filled porosity due to residual effects of poultry manure and fertilizer 
combination were also reported. This was contrary to fertilizer applied alone which reduced some of the above properties (21).Application of 4 and $6 \mathrm{t} \mathrm{PM} / \mathrm{ha}$, combined application of $6 \mathrm{t} \mathrm{PM} / \mathrm{ha}$ plus 50 or $100 \mathrm{~kg} \mathrm{NPK} / \mathrm{ha}$ and $4 \mathrm{t} \mathrm{PM/ha}$ plus $100 \mathrm{NPK} / \mathrm{ha}$ in the year of application and their residual effects in gave higher exchangeable $\mathrm{Mg}, \mathrm{K}, \mathrm{Ca}$ and ECEC when compared to the control in both years.Soil $\mathrm{pH}$, organic carbon, total $\mathrm{N}$ and available $\mathrm{P}$ were significantly enhanced by poultry manure application and the combined application in the first year (22). Combination of poultry and cattle manures gave better leaf area of $1.445 \mathrm{~cm}$ over either of cattle and poultry manure which were 1.191 and $1.215 \mathrm{~cm}$, respectively. Poultry waste alone has the highest yield of $854 \mathrm{~kg} \mathrm{ha}^{-1}$. With the manures soil organic matter increased from $438 \mathrm{mg} \mathrm{L}^{-1}$ for control plot to $865 \mathrm{mg} \mathrm{L}^{-1}$ on poultry and cattle manure plot while the electrical conductivity increased from $66.7-90 \mathrm{dS} \mathrm{m}^{-1}(23)$. NPK fertilizer have been reported to increase stem girth and number of leaves more than poultry manure; relative to the control, 2, 4, $6 \mathrm{t}$ $\mathrm{ha}^{-1}$ of poultry manure and NPK fertilizer increased number of branches by 6.01, 7.01, 7.23, 7.72 and 6.89\%, respectively. The increases in number of leaves were 16.57, 20.17, 20.12, 20.63 and 22.50\%. However, the, they recommended application of $6.0 \mathrm{t} \mathrm{ha}^{-1}$ manure (Awodun , 2007). It has been reported higher profuse leaves, branches and shoot dry matter yield of Amaranthuscruentus due to the application of organic $\mathrm{N}$ (poultry manure) when compared to inorganic $\mathrm{N}$ (urea) (24). Hence the study was conducted to determine the application of poultry manure and NPK fertilizer and their residual effects on the yield and yield components of tomato.

\section{Materials and Methods}

The study was carried out in two distinct locations: Agbede (derived savanna) and Obadan (forest) of Edo State, Nigeria. Edo State is located between Latitudes $5^{\circ} 4^{\mathrm{II}}$ and $7^{0}$ and $38^{\mathrm{II}}$ and Longitudes $5^{0} 4^{\mathrm{II}}$ and $7^{0} 38^{\mathrm{II}}$ of the equator. The State has a mean rainfall of $1300 \mathrm{~mm}$ around Auchi and about $2300 \mathrm{~mm}$ in Benin City (25). Agbede soils were earlier classified as RhodicPaleustalfs while Obadan soil as RhodicPaleudult. The physicochemical properties of the soils before the experiment are shown in Table 1.

Treatments consisted of three levels of poultry manure $\left(0,4\right.$ and 6 ton ha $\left.{ }^{-1}\right)$ and four levels of NPK 15:15:15 fertilizer $\left(0,50,100\right.$ and $\left.150 \mathrm{~kg} \mathrm{ha}^{-1}\right)$ that were combined factorially and fitted into randomized block design. The twelve treatment combinations were replicated three times. Tomato seedlings were transplanted to the field at a spacing of $50 \mathrm{~cm} \times 100 \mathrm{~cm}(2)$. Fertilizer was applied by broadcasting at a week after transplanting by band placement and poultry manure was applied three weeks before transplanting in order to equilibrate with the soils. Data on plant height, leaf area at 3,6 and $9 \mathrm{WAP}$, fruit number and yield were collected and subjected to statistical analysis. Means were separated using Duncan Multiple Range Test (26).

\section{Results}

The results of the analysis of the soil and manure used for the experiment are presented in Table 1. The $\mathrm{N}, \mathrm{P}$ and $\mathrm{K}$ contents of the poultry manure were high, however, available $\mathrm{P}$ was highest.Tomato plant height and leaf area are presented in Tables 2 and 3, respectively. Application of 6 ton PM ha ${ }^{-1}+$ plus 50kgNPK ha ${ }^{-1}$ in 2005 resulted in higher plant height of 66.00 and 63.33 and $100 \mathrm{~cm}$ at 3,6 and 9 weeks after planting (WAP) in Agbede soils. In 2006, residual treatment resulted in plant height of 27.67 and $42.50 \mathrm{~cm}$ at 3 and 6 WAP while at 9 WAP, application of $6 \mathrm{t} \mathrm{PM} \mathrm{ha}{ }^{-1}+150 \mathrm{NPKha}^{-1}$ resulted in the highest plant height of $53.67 \mathrm{~cm}$. In Obadan soils, application of $4 \mathrm{t} \mathrm{PM} \mathrm{ha}{ }^{-1}+50 \mathrm{~kg} \mathrm{NPKha}^{-1}$ in 2005 , resulted in plant heights of $45.57,67.33$ and $103.67 \mathrm{~cm}$ at 3, 6 and 9 WAP, respectively. But in 2006, its residual effect yielded the highest plant height of 52.22 and $71.79 \mathrm{~cm}$ at 3 and $6 \mathrm{WAP}$, respectively. Application of $4 \mathrm{t} \mathrm{PM} \mathrm{ha}{ }^{-1}$ in 2005 significantly produced taller plants in Obadan soils but in 2006 it was the residual effect of $6 \mathrm{t} \mathrm{PM} \mathrm{ha}^{-1}$. Similar results were obtained in Agbede in 2005 and in 2006.

Leaf area of 19.77, 20.85, and $22.58 \mathrm{~cm}^{2}$ (Table 4) were obtained at 3, 6 and 9 WAP, respectively in Agbede soils. Residual 4 ton PM ha ${ }^{-1}+50 \mathrm{~kg} \mathrm{NPK} \mathrm{ha}^{-1}$ in 2006 produced plants with the highest leaf area. In both years, poultry manure at 9 WAP produced plants with better leaf area when compared to NPK fertilizer in Agbede soils. In 2005 application of 6 ton PM ha ${ }^{-1}+50 \mathrm{~kg} \mathrm{NPK} \mathrm{ha}^{-1}$ resulted in leaf area of 18.16 and $27.23 \mathrm{~cm}^{2}$ (Table 5) when compared to 2.74 and $4.10 \mathrm{~cm}^{2}$ of the control in Obadan soils at 3 and 6 WAP, respectively. At 9 WAP, the highest leaf area of $30.33 \mathrm{~cm}^{2}$ was obtained from the application of 6 ton PM ha ${ }^{-1}+150 \mathrm{~kg}$ NPK ha-1. Residual 6 ton PM ha ${ }^{-1}+100 \mathrm{~kg} \mathrm{NPK} \mathrm{ha}^{-1}$ in 2006 significantly gave higher leaf area in all the weeks after planting. NPK fertilizer alone in both years was least.

In Agbede soils, application of $6 \mathrm{t} \mathrm{PM} \mathrm{ha}^{-1}+50 \mathrm{~kg} \mathrm{NPK} \mathrm{ha}^{-1}$ in 2005 significantly had the highest fruit number (68.33) when compared to 7.67 obtained of the control. Its residual effect gave the highest fruit number of 45.00 in 2006. The effect of poultry manure alone was significantly better in 2005 and also residually better in 2006 when compared to the control in enhancing fruit numbers. NPK fertilizer alone decreased fruit numbers. Application of $50 \mathrm{~kg} \mathrm{NPK} \mathrm{ha}^{-1}$ was significantly better than higher levels. In Obadan soils $6 \mathrm{t} \mathrm{PM} \mathrm{ha}^{-1}+50 \mathrm{~kg}$ NPK ha ${ }^{-1}$ application gave higher fruit numbers in 2005 while $6 \mathrm{t} \mathrm{PM} \mathrm{ha}^{-1}+150 \mathrm{~kg} \mathrm{NPK} \mathrm{ha}^{-1}$ was residually more effective in 2006 (Table 7). Poultry manure alone in 2006 was residually better while NPK fertilizer alone in $2005\left(50 \mathrm{~kg} \mathrm{NPK} \mathrm{ha}^{-1}\right)$ gave higher fruit numbers when compared to poultry manure alone. 
In Agbede soils, the application of $6 \mathrm{t} \mathrm{PM} \mathrm{ha}^{-1}+50 \mathrm{~kg} \mathrm{NPK} \mathrm{ha}^{-1}$ gave better fruit yield in 2006 when compared to 2005 (Table 6). Poultry manure application in both years $\left(6 \mathrm{t} \mathrm{PM} \mathrm{ha}^{-1}\right)$ significantly gave higher fruit yield and was better than NPK fertilizer applied in 2005 and its residual effects in 2006.In Obadan soils, application of $6 \mathrm{t} \mathrm{PM} \mathrm{ha}{ }^{-1}+100 \mathrm{~kg} \mathrm{NPK} \mathrm{ha}^{-1}$ in 2005 and its residual in 2006 gave the highest fruit yield of 3.42 and $2.85 \mathrm{t}$ $\mathrm{ha}^{1}$. Application of NPK fertilizer alone gave fruit yield of 2.72 tha $^{-1}$ in 2005. Residually in 2006, application of $4 \mathrm{tha}^{-1}$ gave slightly higher fruit yield.

\section{Discussion}

In both locations, tomato plant height and leaf area increased in 2005 and residually in 2006 with combined application of poultry manure and NPK fertilizer $\left(6\right.$ ton PM ha $\left.{ }^{-1}+50 \mathrm{~kg} \mathrm{NPK} \mathrm{ha}^{-1}\right)$ in all the weeks after planting. Application of poultry manure alone was significantly better in enhancing growth in both years when compared to NPK fertilizer application. The enhancement of growth over the control irrespective of source (organic and/or inorganic) showed the importance of $\mathrm{N}$ contained in both sources. Manure is a possible alternative source of nutrient for crop production (27). This is because organic manure is regarded as a storehouse of primary and trace elements (28). Poultry manure becomes more efficient when combined with other mineral fertilizer (29). Application of poultry manure alone or in combination with $\mathrm{N}$ fertilizer exerts much more beneficial effects on plant height and yield when compared to single application of $\mathrm{N}$ (30).

It was observed that tomato fruit yield was comparably higher in the forest soils (Obadan) in 2005 and residually in 2006 than in the derived savanna soils (Agbede) with about 55\% and $45 \%$ increases as a result of the combined application. Moreover, the contribution of poultry manure was similar to that of NPK fertilizer in Obadan soils while in Agbede soils in 2005 and residually in 2006 poultry manure enhanced fruit yield better than NPK fertilizer contribution. The relative increase in yield by combined application NPK and poultry manure of could be attributed to improvement in soil structure, nutrient retention and water for plant use (31). This could possibly explain the superiority of organic sources and combined application. The enhanced performance of combined application when compared to poultry manure or NPK fertilizer alone could be attributed to release of plant nutrient elements and organic matter addition $(32,33)$. Residual benefits during years of no manure application have been reported (34).

\section{Conclusion}

Results of the study revealed that application of 4 to 6 ton ha ${ }^{-1}$ of poultry manure and its residual effects appeared to be good for tomato production. Application of fertilizer alone proved less effective when compared to poultry manure alone. However, combined application of NPK fertilizer and poultry manure had shown to be more effective. A combined application of 6 ton PM ha ${ }^{-1}+100 \mathrm{~kg} \mathrm{NPK} \mathrm{ha}^{-1}$ is recommended for tomato cultivation in forest zone while 6 ton PM ha ${ }^{-1}$ and $50 \mathrm{~kg} \mathrm{NPK} \mathrm{ha}^{-1}$ is recommended for the derived savanna zone for tomato cultivation.

\section{References}

[1]. R.N. Leister, and A. Seck,Solanumaethiopicum L. Record from protobase. Oyen, L.P.A and Lemmens, R.H. (ed). PROTA (Plant Resources of Tropical Africa/ Resources Vegetables. 2002

[2]. I.C. Onwueme, Crop Science (Macmillan Publication. Ltd., 1989). 72 - 75.

[3]. J.H. Simon, and R.A. Sobulo, Methods for higher tomato yield in Western State of Nigerian. Paper presented at Institute of Agric. research Conference. Ibadan, Nigeria, 1974

[4]. J.O. Ehigiator, Farm yard manure; needs for its adoption as an alternative to chemical fertilizers uses in Nigeria. Nigerian Journal of Horticultural Science, 3, 1998, 19.

[5]. L. Mukurunbira, Recycling of crop residue to supplement $\mathrm{N}$ requirement of maize in Zambia.In report of the Tropical Soil Biology and Fertility Programme.Paul, D. S and Paul, L.W (eds), 1992, 48.

[6]. S.M. Nandu, The effects of stover placement on soil properties and processes and productivity of maize in teo agro-ecosystem in Kenya. In report of Tropical Soil Biology and Fertility Programme. D. S. Paul and L.W. Paul, (eds) 48p.

[7]. W.B. Akanbi, A.O. Togun, and R.A. Baiyewu, Suitability of plant residue compost as nursery growing medium for some tropical fruit tree Seedlings. Moor Journal of Agricultural Research 2, 2001:41-45.

[8]. J. Mclintire, Constraints of fertilizer use in sub- Saharan Africa. In management of nitrogen and phosphorus fertilizers in subSaharan Africa. A.U. Mokwunye and P.L.G. Vlek (eds). Proceedings of a symposium, Lome, Togo.MartinusNijhoff Publication. The Netherlands March 25-28, 1986, 35-37.

[9]. I. Odiete, and S.O. Ogunmoye, Comparative effect of poultry manure and phosphorus fertilizer on the growth and yield of soybean (Glycine max) in Plateau State. The Proceedings of the $39^{\text {th }}$ annual conference of the Agricultural Society of Nigeria, Benin City, $2005,258-259$.

[10]. J.P. Zublena, J.C. Baker, andT.A. Carter,Poultry manure as a fertilizer source. North Carolina Cooperative Extension Service.SoilFacts.Raleign.http://www.soil.ncsu.edu/publications/soil facts/AG-439-05, 1997.

[11]. E.O. Uyovbisere,V.O. Chude, and A. Bationo, Promising nutrient ratios in fertilizer formulations for optimal performance of maize in the Nigerian savanna. The need for a review.Nigeria Journal of Soil Research, 1, 2000, 29 - 34.

[12]. S. Harty, G.C. Clary, P. Hargis, and S. Reeves, Poultry litter a fertilizer production alternative for plant and animal agriculture. Miscellaneous Publications.TexasAgricultural Extension Services, College Station.Texas, 1992.

[13]. N.U. Nadaeyo, E.S. Ukpong,and N.M John, Performances of okra as affected by organic and inorganic fertilizers on an ultisol. Proceedings of the $39^{\text {th }}$ conference of the Agricultural Society of Nigeria, Benin City, 2005, 206-208. 
[14]. S.A. Odedina, Evaluation of NPK rate combinations for maize production in humid zones of Nigeria. Nigeria Journal of Soil Science, 15(2), 2005, 111-115.

[15]. S.U. Remison, Some advances in research on root/tuber crops in Edo State of Nigeria. First Faculty of Agriculture Staff Seminar Series, Ambrose Alli University, Ekpoma, 2007, 137.

[16]. K.M. Giller, Misiko, and P. Tittonell, Managing organic resources for soil amendment. LEISA. Vol. 22 (4), 2006, 16-17.Henao, J and Baanante, C. (1999).Nutrient depletion in the agricultural soils of Africa.

[17]. M.E. Obi, and P.O. Ebo, The effect of different management practices on the soil physical properties and maize production in a severely degraded soil in southern Nigeria. Biological Resource Technologyl.51, 1995, 117 - 123.

[18]. C.A. Palm, R. K. J. Myers, and S.M. Nandwa, Combined use of organic and inorganic nutrient sources for soil fertility maintenance and replenishment. In replanting soil fertility in Africa (eds). Buresh, R.J; P.A. Sanchez, and F. Calhoun.Soil Science Society of America, Madison, WI.Special Publication51, 1997, $193-217$.

[19]. A.L. Blandari, K.N. Sharma, M.L. Kapur, and D.S. Rana, Supplementation of nitrogen through green manuring for maize growing. Journal of Indian Society of Soil Science 37, 1989, $483-486$.

[20]. M.S. Zeidan, Effect of organic manure and phosphorus fertilizers on growth, yield, and quality of lentil plants in sandy soil. Res. $J$. Agric.Biol. Sci., 3, 2007, 748-752

[21]. H.H.E, Isitekhale, and I.O. Osemwota, Residual effects of poultry manure and NPK fertilizer on nutrient contents and uptake by tomato in the forest and derived savanna soils of Edo State. Nigerian Journal of Soil Science, Vol. 20(2), 2010, 17-25.

[22]. H.H.E, Isitekhale, and I.O. Osemwota,Residual effects of poultry manure and NPK fertilizer on soil physical properties in the forest and derived savanna soils of Edo State. Nigerian Journal of Soil Science. Vol. 20(2), 2010, 26-34.

[23]. P.A. Adeoye,S.E. AdebayoandJ.J. Musa, Growth and yield response of cowpea (Vignaunguiculata) to poultry and cattle manure as amendments on sandy loam soil plot, Agricultural Journal, 6(5), 2011, 218-221

[24]. A. Daramola, S. Adeyeye, and D. Lawal, Effects of application of organic and inorganic nitrogen fertilizers on the growth and dry matter yield of amarathus. Proceeding of the $2^{\text {nd }}$ National conference of Organic Agriculture in Nigeria, 2006, $78-83$.

[25]. EADP. (1995). Edo Agricultural Development Programme Main Station, Irrua, EsanWest L.G.A, Ekpoma, Edo state, Nigeria.

[26]. H. Frank, and S.C. Althoen, Statistics concepts and applications. Low price (ed) (Cambridge University Press), 1995, 539.

[27]. A.A. Agboola, and P.A. Unamma, Maintenance of soil fertility under traditional farming system. Proceedings of National Organic Fertilizer Seminar held in Kaduna, 1991, 7-42.

[28]. J. Janic,Horticultural Science, 4th edition, (W. H. Freeman and Company N) 1986. 4746.

[29]. K.H. Murwira, M.J. Swift, and P.G.H. Frost, Manure as a key resource in sustainable agriculture. In Powel, J.A, S. FernandezRivera, T.O. Williams and C.Renard (eds). Livestock and sustainable nutrient recycling in mixed farming systems in sub- Saharan Africa. Vol. II : Technical Papers. Proceedings of an International Conference held in Addis Abba, Ethiopia, ILCA (International Livestock Centre for Africa), 1995.

[30]. U.L. Arunah,U.F.Chiezey, L.Aliyu,B.A. Babaji, E.C. Odion,andB.M.Sani, Application of inorganic fertilizers and poultry manure on

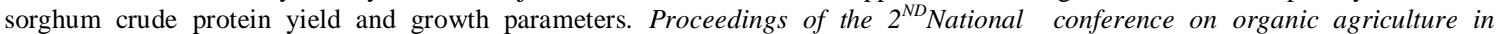
Nigeria.2006, $114-117$.

[31]. A.C. Anyawu, B.O. Anyangu, and V.A. Anyanwu,A textbook of Agricultural Science for schools and colleges. African Fep Publishers Ltd. Onitsha, Nigeria.2001, 431.

[32]. P.L. Woomer, and F.N Muchana, Overcoming soil constraints in crop production in tropical Africa. In Y. Ahenhora; E. OwusuBennoah, G.N.N. 1993.In U.L. Arunah, U.F. Chiezey; L. Aliyu; B.A. Babaji; E.C. Odion and B.M. Sani.Application of inorganic fertilizers and poultry manure on sorghum crude protein, yield and growth parameters. $2^{\text {nd }}$ Conference of organic Agriculture Nigeria, 2006:114-115

[33]. J. Henao, andC. Baanante, Nutrient depletion in the agricultural soils of Africa. 2020 vision brief 62. Washington, D.C. Institute Food Policy Research Institute, 1999.

[34]. CREES (Cooperative State Research, Education and Extension Services). 2020 vision brief 62. Washington, D.C. Institute Food Policy Research Institute, 2006.

Table 1 Properties of the experimental soils and poultry manure used for the experiments.

PARAMETERS

$\mathrm{pH}$

Organic carbon $\mathrm{g} / \mathrm{kg}$

Total $\mathrm{Ng} / \mathrm{kg}$

Available P

Exch. Cations $(\mathrm{cmol} / \mathrm{kg})$

$\mathrm{Ca}$

$\mathrm{Mg}$
SOILS

Agbede

20052006

$\begin{array}{lllll} & 5.00 & 5.53 & 6.35 & 5.55\end{array}$

6.81

8.85

10.00

12.15

3.17

0.60

0.85

1.70

1.98

9.81

8.63

10.52

6.20

61.29

Poultry manure

$\begin{array}{llllll} & 2.98 & 2.10 & 4.52 & 2.20 & 38.08 \\ \mathrm{Mg} & 0.51 & 0.60 & 2.05 & 1.10 & 4.16\end{array}$




\begin{tabular}{llllll}
\hline $\mathrm{K}$ & 0.21 & 0.10 & 0.18 & 0.19 & 2.28 \\
$\mathrm{Na}$ & 0.25 & 0.23 & 0.54 & 0.20 & 1.18 \\
$\mathrm{H}+$ & 0.31 & 0.18 & 0.55 & 0.24 & 0.60 \\
$\mathrm{Al+}$ & - & - & - & - & 0.30 \\
ECEC & 3.19 & 3.21 & 7.91 & 3.93 & 47.60 \\
Particle size $(\mathrm{g} / \mathrm{kg})$ & & & & \\
Clay & 69.70 & 40.33 & 85.00 & 45.00 & \\
Silt & 25.30 & 20.00 & 24.00 & 22.70 & \\
Sand & 905.00 & 939.67 & 891.00 & 932.00 & \\
Texture & Sand & Sand & Loamy & Sand \\
\end{tabular}

Table 2.Effect of poultry manure and fertilizer on mean plant height in Agbede soils

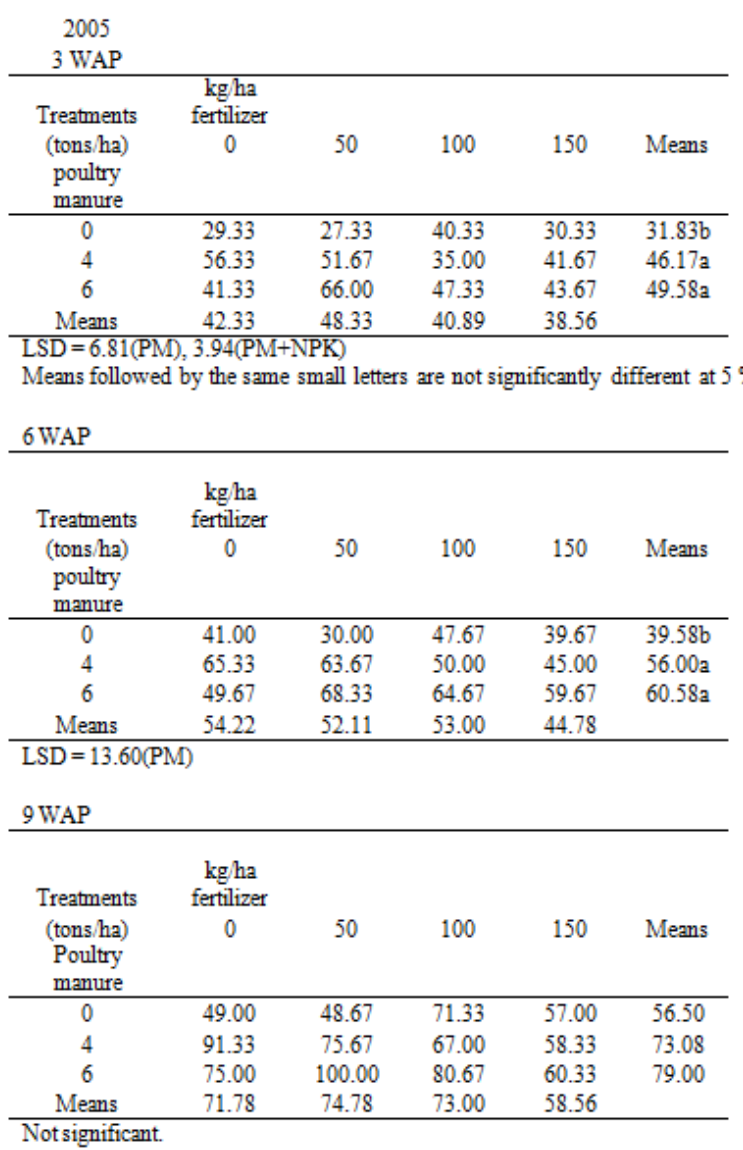

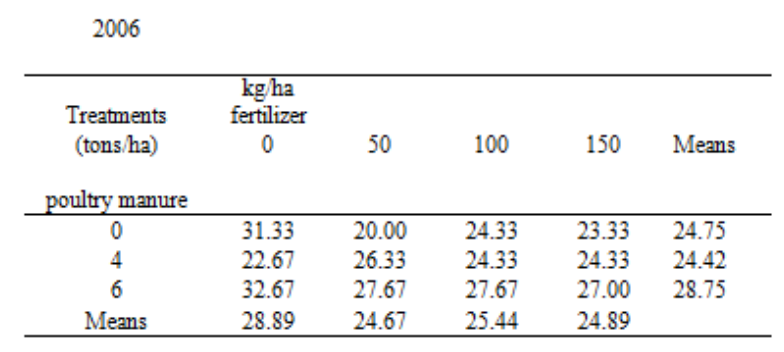

level

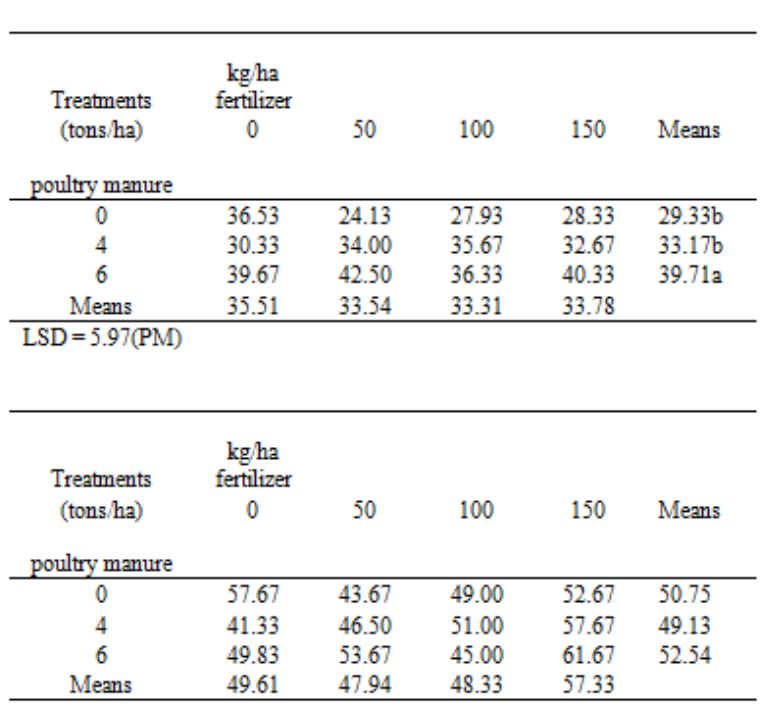


Table 3 Effect of poultry manure and NPK fertilizer on plant height in Obadan soils

\begin{tabular}{|c|c|c|c|c|c|c|c|c|c|c|c|}
\hline \multicolumn{12}{|l|}{$\frac{3 \text { WAP }}{2005}$} \\
\hline Treatments & $\begin{array}{c}\mathrm{kg} / \mathrm{ha} \\
\text { fertilizer }\end{array}$ & & & & & Treatments & $\begin{array}{c}\mathrm{kg} / \mathrm{ha} \\
\text { fertilizer }\end{array}$ & & & & \\
\hline $\begin{array}{l}\text { (tons/ha) } \\
\text { poultry } \\
\text { manure }\end{array}$ & 0 & 50 & 100 & 150 & Means & $\begin{array}{l}\text { (tons } / \mathrm{ha} \text { ) } \\
\text { poultry } \\
\text { manure }\end{array}$ & 0 & 50 & 100 & 150 & Means \\
\hline 0 & 26.33 & 26.00 & 33.50 & 28.10 & & 0 & 20.36 & 20.37 & 22.00 & 25.28 & $22.01 \mathrm{~b}$ \\
\hline 4 & 44.87 & 47.57 & 33.33 & 27.17 & & 4 & 42.95 & 52.22 & 36.02 & 32.67 & $40.96 \mathrm{a}$ \\
\hline 6 & 34.87 & 37.87 & 40.47 & 38.20 & & 6 & 33.93 & 40.74 & 45.93 & 44.34 & $41.23 \mathrm{a}$ \\
\hline Means & 35.36 & 37.14 & 35.77 & 31.16 & & Means & 32.42 & 37.77 & 34.65 & 34.09 & \\
\hline & & & \multicolumn{9}{|c|}{$\mathrm{LSD}=3.81(\mathrm{PM}), 2.20(\mathrm{PM}+\mathrm{NPK})$} \\
\hline \multicolumn{12}{|l|}{$6 \mathrm{WAP}$} \\
\hline $\begin{array}{c}\text { Treatment } \\
\text { (tons } / \text { ha) } \\
\text { poultry } \\
\text { manure }\end{array}$ & $\begin{array}{c}\mathrm{kg} / \mathrm{ha} \\
\text { fertilizer } \\
0\end{array}$ & 50 & 100 & 150 & Means & $\begin{array}{c}\text { Treatments } \\
\text { (tons/ha) } \\
\text { poultry } \\
\text { manure }\end{array}$ & $\begin{array}{c}\mathrm{kg} / \mathrm{ha} \\
\text { fertilizer } \\
0\end{array}$ & 50 & 100 & 150 & Means \\
\hline 0 & 15.91 & 39.00 & 50.33 & 42.33 & 42.83 & 0 & 28.01 & 33.23 & 30.02 & 52.27 & $37.38 \mathrm{~b}$ \\
\hline 4 & 67.33 & 67.33 & 50.00 & 40.67 & 56.33 & 4 & 66.52 & 71.79 & 56.31 & 48.81 & $60.86 \mathrm{a}$ \\
\hline 6 & 47.00 & 57.33 & 60.67 & 57.33 & 55.58 & 6 & 55.05 & 59.54 & 60.45 & 68.44 & $60.87 \mathrm{a}$ \\
\hline Means & 43.41 & 54.56 & 53.67 & 46.67 & & Means & 49.86 & 54.86 & 50.93 & 56.51 & \\
\hline $\mathrm{LSD}=16.94$ & & & & & & $\mathrm{LSD}=8.66$ &, $5.00(\mathrm{PN}$ & & & & \\
\hline \multicolumn{12}{|l|}{$9 \mathrm{WAP}$} \\
\hline Treatments & $\begin{array}{c}\mathrm{kg} / \mathrm{ha} \\
\text { fertilizer }\end{array}$ & & & & & Treatments & $\begin{array}{c}\mathrm{kg} / \mathrm{ha} \\
\text { fertilizer }\end{array}$ & & & & \\
\hline $\begin{array}{c}\text { (tons/ha) } \\
\text { poultry } \\
\text { manure } \\
\end{array}$ & 0 & 50 & 100 & 150Mean & & $\begin{array}{c}\text { (tons/ha) } \\
\text { poultry } \\
\text { manure }\end{array}$ & 0 & 50 & 100 & 150 & Means \\
\hline 0 & 45.67 & 51.00 & 71.33 & 69.00 & 59.25 & 0 & 34.43 & 42.19 & 45.46 & 66.22 & $47.08 \mathrm{~b}$ \\
\hline 4 & 84.33 & 103.67 & 74.33 & 64.00 & 81.58 & 4 & 72.12 & 87.37 & 68.81 & 74.23 & $75.63 \mathrm{a}$ \\
\hline 6 & 67.67 & 70.33 & 74.67 & 73.67 & 71.58 & 6 & 76.01 & 85.37 & 71.47 & 88.31 & $80.29 \mathrm{a}$ \\
\hline Means & 65.89 & 75.00 & 73.44 & 68.89 & & Means & 60.86 & 71.64 & 61.91 & 76.25 & \\
\hline
\end{tabular}

Means followed by the same small letters arenot significantly different at $5 \%$ level.

Table 4. Effect of poultry manure and NPK fertilizer on mean tomato leaf area in Agbede soils.

\begin{tabular}{|c|c|c|c|c|c|c|c|c|c|c|c|}
\hline \multicolumn{6}{|l|}{$\begin{array}{c}2005 \\
3 \text { WAP }\end{array}$} & \multicolumn{6}{|l|}{2006} \\
\hline $\begin{array}{c}\text { Treatments } \\
\text { (tons/ha) } \\
\text { poultry } \\
\text { manure }\end{array}$ & $\begin{array}{c}\mathrm{Kg} / \mathrm{ha} \text { fertilizer } \\
0\end{array}$ & 50 & 100 & 150 & Means & $\begin{array}{c}\text { Treatments } \\
\text { (tons/ha) } \\
\text { poultry } \\
\text { manure }\end{array}$ & $\begin{array}{c}\mathrm{kg} / \mathrm{ha} \text { fertilizer } \\
0\end{array}$ & 50 & 100 & 150 & Means \\
\hline 0 & 5.40 & 7.60 & 12.13 & 6.57 & 7.93 & 0 & 7.70 & 7.73 & 6.20 & 8.80 & $7.61 \mathrm{~b}$ \\
\hline 4 & 15.33 & 13.87 & 9.57 & 7.80 & 11.69 & 4 & 12.17 & 9.50 & 19.23 & 10.80 & $12.93 \mathrm{a}$ \\
\hline 6 & 11.50 & 19.77 & 5.10 & 10.90 & 11.82 & 6 & 14.83 & 9.83 & 10.53 & 8.73 & $10.98 \mathrm{a}$ \\
\hline Means & 10.81 & 13.74 & 8.93 & 8.42 & & Means & 11.57 & 9.02 & 11.99 & 9.44 & \\
\hline \multicolumn{6}{|c|}{$\mathrm{LSD}=2.20(\mathrm{PM}+\mathrm{NPK})$} & \multicolumn{6}{|c|}{ LSD $=3.01(\mathrm{PM})$} \\
\hline \multicolumn{12}{|l|}{$6 \mathrm{WAP}$} \\
\hline $\begin{array}{c}\text { Treatments } \\
\text { (tons/ha) } \\
\text { poultry } \\
\text { manure }\end{array}$ & $\begin{array}{c}\mathrm{kg} / \mathrm{ha} \text { fertilizer } \\
0\end{array}$ & 50 & 100 & 150 & Means & $\begin{array}{c}\text { Treatments } \\
\text { (tons } / \mathrm{ha} \text { ) } \\
\text { poultry } \\
\text { manure }\end{array}$ & $\mathrm{kg} / \mathrm{ha}$ fertilizer & 50 & 100 & 150 & Means \\
\hline 0 & 8.23 & 9.27 & 14.58 & 10.43 & 10.63 & 0 & 8.47 & 9.30 & 7.60 & 10.57 & 8.98 \\
\hline 4 & 17.37 & 15.13 & 11.70 & 12.28 & 14.12 & 4 & 14.33 & 12.20 & 23.10 & 13.57 & 12.41 \\
\hline 6 & 16.20 & 20.85 & 18.75 & 13.25 & 17.26 & 6 & 17.97 & 12.07 & 12.83 & 10.33 & 13.30 \\
\hline Means & 13.94 & 15.08 & 15.01 & 11.99 & & Means & 13.59 & 27.86 & 14.51 & 11.49 & \\
\hline \multicolumn{12}{|l|}{$9 \mathrm{WAP}$} \\
\hline $\begin{array}{c}\text { Treatments } \\
\text { (tons } / \mathrm{ha} \text { ) } \\
\text { poultry } \\
\text { manure }\end{array}$ & $\begin{array}{c}\mathrm{kg} / \mathrm{ha} \text { fertilizer } \\
0\end{array}$ & 50 & 100 & 150 & Means & $\begin{array}{c}\text { Treatments } \\
\text { (tons } / \mathrm{ha} \text { ) } \\
\text { poultry } \\
\text { manure }\end{array}$ & $\begin{array}{c}\mathrm{kg} / \mathrm{ha} \text { fertilizer } \\
0\end{array}$ & 50 & 100 & 150 & Means \\
\hline 0 & 7.89 & 13.03 & 13.65 & 12.89 & $11.87 \mathrm{~b}$ & 0 & 10.40 & 11.33 & 12.13 & 13.17 & $11.76 \mathrm{~b}$ \\
\hline 4 & 12.77 & 19.44 & 13.70 & 17.75 & $15.92 \mathrm{ab}$ & 4 & 17.66 & 15.07 & 28.13 & 16.97 & $19.46 \mathrm{a}$ \\
\hline 6 & 17.20 & 22.58 & 21.32 & 13.48 & $18.65 \mathrm{a}$ & 6 & 22.40 & 15.07 & 16.20 & 13.33 & $16.70 \mathrm{a}$ \\
\hline Means & 12.62 & 18.35 & 16.22 & 14.71 & & Means & 16.82 & 13.82 & 18.82 & 14.42 & \\
\hline
\end{tabular}


Table 5 Effect of poultry manure and NPK fertilizer on tomato leaf area in Obadan soils.

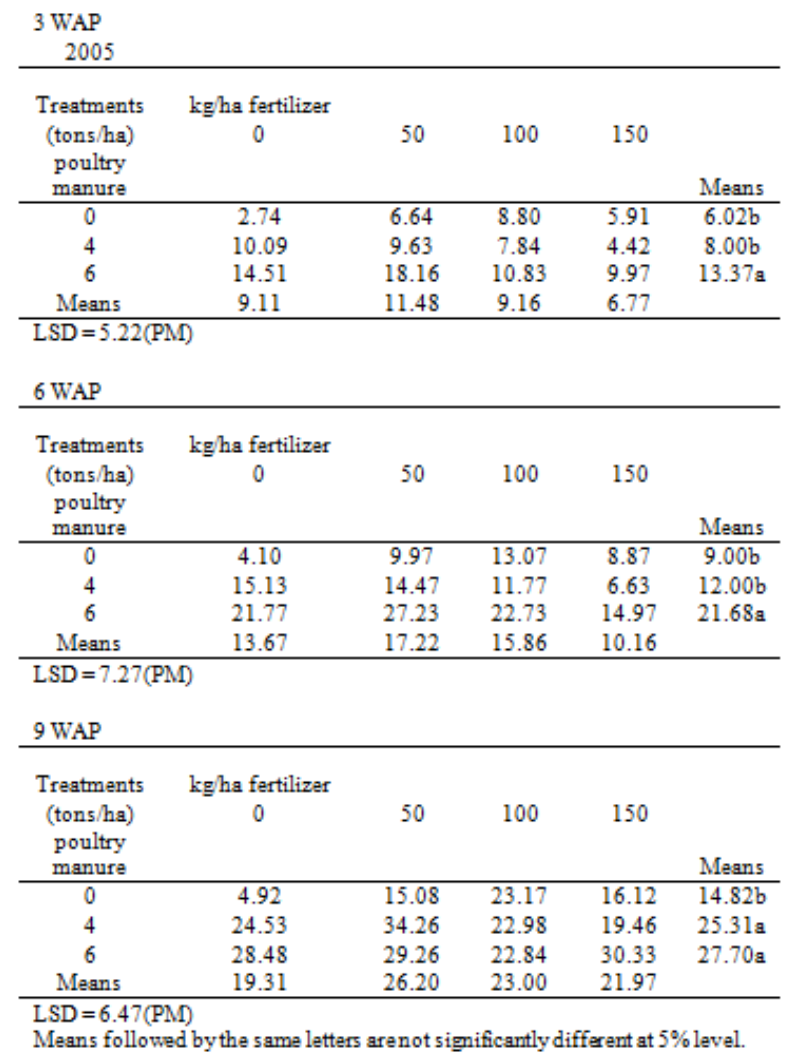

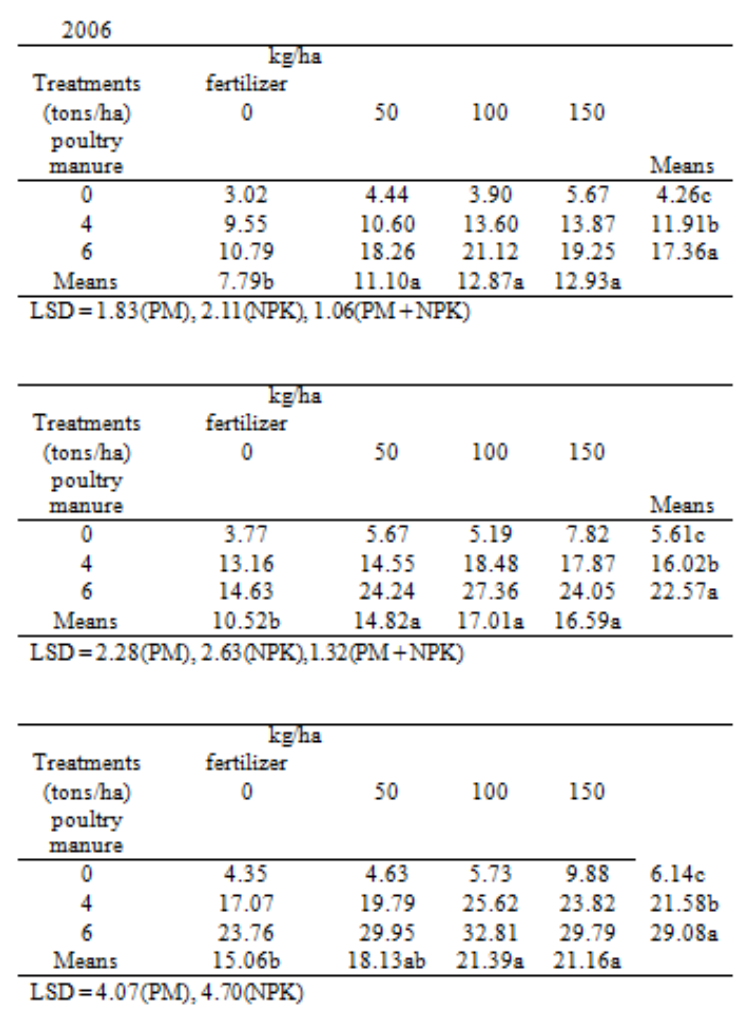

Table 6 Effect of poultry manure and NPK fertilizer on mean tomato yield in Agbede soils.

Fruit

Numbers

2005

2006

\begin{tabular}{lccccc}
$\begin{array}{l}\text { Treatments } \\
\text { (tons/ha) } \\
\text { poultry manure }\end{array}$ & 0 & 50 & \multicolumn{4}{c}{$\mathrm{kghaf}$ fertilizer } \\
& & & 100 & Means \\
\hline 0 & 7.67 & 2.67 & 19.67 & 7.33 & $9.33 \mathrm{c}$ \\
4 & 47.00 & 54.33 & 40.00 & 46.00 & $46.83 \mathrm{a}$ \\
6 & 38.67 & 68.33 & 45.67 & 30.33 & $45.75 \mathrm{~b}$ \\
Means & $31.11 \mathrm{c}$ & $41.78 \mathrm{a}$ & $35.11 \mathrm{~b}$ & $27.89 \mathrm{~d}$ & \\
\hline LSD $=0.21(\mathrm{PM}), 0.23(\mathrm{NPK}), 0.12(\mathrm{PM}+\mathrm{NPK})$ &
\end{tabular}

\begin{tabular}{cccccc}
\cline { 2 - 6 } $\begin{array}{l}\text { (tons ha) } \\
\text { Treatments } \\
0\end{array}$ & 50 & \multicolumn{4}{c}{ kgha fertilizer } \\
poultry manure & & & 150 & Means \\
\hline 0 & 4.67 & 4.33 & 5.33 & 9.00 & $5.83 \mathrm{c}$ \\
4 & 23.33 & 23.67 & 34.33 & 18.67 & $24.25 \mathrm{~b}$ \\
6 & 42.00 & 45.00 & 35.33 & 33.00 & $38.83 \mathrm{a}$ \\
Means & 22.33 & 24.33 & 25.00 & 20.22 & \\
\hline \multicolumn{5}{l}{ LSD $=7.39$ (PM) }
\end{tabular}

Fruit Yield (tons/ha)

2005

2006

\begin{tabular}{lccccc}
$\begin{array}{l}\text { Treatments } \\
\text { (tons/ha) } \\
\text { poultry marure }\end{array}$ & 0 & 50 & 100 & 150 & Means \\
\hline 0 & 0.35 & 0.22 & 0.22 & 1.01 & $0.45 \mathrm{c}$ \\
4 & 1.08 & 0.98 & 1.31 & 1.41 & $1.20 \mathrm{~b}$ \\
6 & 1.75 & 1.44 & 1.25 & 1.53 & $1.49 \mathrm{a}$ \\
Means & $1.06 \mathrm{~b}$ & $0.88 \mathrm{c}$ & $0.93 \mathrm{c}$ & $1.32 \mathrm{a}$ & \\
\hline
\end{tabular}

$\mathrm{LSD}=0.21(\mathrm{PM}), 0.24(\mathrm{NPK}), 0.12(\mathrm{PM}+\mathrm{NPK})$

Means followed by the same small letters arenot significantly different at $5 \%$ level.

Treatments $\mathrm{kg} / \mathrm{hafertilizer}$

$\begin{array}{llllll}\text { (tonsha) } & 0 & 50 & 100 & 150 & \text { Means }\end{array}$

poultry marure

\begin{tabular}{cccccc}
\multicolumn{2}{l}{ poultry manure } & & & & \\
\hline 0 & 0.19 & 0.11 & 0.27 & 0.60 & $0.29 \mathrm{~b}$ \\
4 & 0.95 & 0.97 & 1.15 & 1.07 & $1.04 \mathrm{a}$ \\
6 & 1.26 & 1.55 & 1.21 & 1.21 & $1.31 \mathrm{a}$ \\
Means & 0.80 & 0.88 & 0.88 & 0.96 & \\
\hline
\end{tabular}

$\mathrm{LD}=0.72$ (PM) 
Table7 Effect of poultry manure and NPK fertilizer on mean tomato yield in Obadan soils.

\begin{tabular}{cccccc}
$\begin{array}{c}\text { Fruitnumbers } \\
2005\end{array}$ & & & & & \\
\hline $\begin{array}{c}\text { Treatments } \\
\text { (tons } / \text { ha })\end{array}$ & $\begin{array}{c}\text { kgha fertilizer } \\
0\end{array}$ & 50 & 100 & 150 Means & \\
poultry manure & & & & & \\
\hline 0 & 11.33 & 12.00 & 15.33 & 6.33 & $11.25 \mathrm{~ns}$ \\
4 & 20.67 & 32.33 & 13.33 & 21.00 & $21.83 \mathrm{~ns}$ \\
6 & 16.33 & 33.33 & 25.33 & 15.00 & $22.50 \mathrm{~ns}$ \\
Means & 16.11 & 25.89 & 18.00 & 14.11 & \\
\hline
\end{tabular}

\begin{tabular}{cccccc}
2006 & & & & & \\
\hline $\begin{array}{c}\text { Treatments } \\
\text { (tons/ha) } \\
\text { poultry } \\
\text { manure }\end{array}$ & $\begin{array}{c}\text { kgha fertilizer } \\
0\end{array}$ & 50 & 100 & 150 & Means \\
\hline 0 & 8.00 & 9.00 & 11.67 & 6.00 & 8.676 \\
4 & 12.67 & 19.33 & 12.33 & 19.33 & $15.92 \mathrm{a}$ \\
6 & 12.33 & 9.00 & 16.67 & 19.67 & $14.42 \mathrm{a}$ \\
Means & 11.00 & 12.44 & 13.56 & 15.00 & \\
\hline LSD $=5.80(\mathrm{PM})$ & & & & &
\end{tabular}

Fruityield (tons ha)

\begin{tabular}{|c|c|c|c|c|c|}
\hline $\begin{array}{c}\text { Treatments } \\
\text { (tons /ha) }\end{array}$ & $\begin{array}{c}\text { kgha fertilizar } \\
0\end{array}$ & 50 & 100 & 150 Means & \\
\hline poultry manure & & & & & \\
\hline 0 & 0.82 & 1.42 & 1.78 & 0.72 & $1.18 \mathrm{~b}$ \\
\hline 4 & 2.27 & 2.47 & 2.97 & 2.67 & $2.59 \mathrm{a}$ \\
\hline 6 & 1.83 & 1.37 & 3.42 & 2.30 & $2.23 \mathrm{a}$ \\
\hline Means & 1.64 & 1.75 & 2.72 & 1.89 & \\
\hline
\end{tabular}

\begin{tabular}{|c|c|c|c|c|c|}
\hline $\begin{array}{c}\text { Treatments } \\
\text { (tons/ha) } \\
\text { poultry } \\
\text { manure }\end{array}$ & $\begin{array}{c}\text { kgha fertilizer } \\
0\end{array}$ & 50 & 100 & 150 & Means \\
\hline 0 & 0.66 & 1.14 & 1.71 & 0.63 & $1.04 \mathrm{c}$ \\
\hline 4 & 2.13 & 2.29 & 2.65 & 2.55 & $2.41 \mathrm{a}$ \\
\hline 6 & 1.69 & 1.31 & 2.85 & 1.93 & $1.95 \mathrm{~b}$ \\
\hline Means & $1.49 \mathrm{~b}$ & $1.58 \mathrm{~b}$ & $2.40 \mathrm{a}$ & $1.70 \mathrm{~b}$ & \\
\hline
\end{tabular}

Means followed by the same small letters arenot significartly different at $5 \%$ level. 